Higher Ground 
DUKE UNIVERSITY PRESS Durham and London 2006 


\section{Higher Ground}

Ethics and Leadership in the Modern University 
(C) 2006 DUKE UNIVERSITY PRESS

All rights reserved.

Printed in the United States of America

on acid-free paper

Designed by C. H. Westmoreland

Typeset in ITC Stone by Keystone Typesetting, Inc.

Library of Congress Cataloging-in-Publication Data

Keohane, Nannerl O., I940-

Higher ground : ethics and leadership in

the modern university / Nannerl O. Keohane.

p. cm.

Includes bibliographical references and index.

ISBN o-8223-3786-X (cloth : alk. paper)

I. Education, Higher-Administration.

2. Education, Higher-Moral and ethical aspects.

3. Education, Higher-Aims and objectives.

I. Title.

LB234I.K39 2006

I74'.9378-dc22 2005030739

Duke University Press gratefully acknowledges the support of trustee emerita Dorothy Lewis Simpson W' 46 and W. Hunter Simpson, who have contributed generously toward the production and distribution of this book. 